\title{
Targeting adipose tissue
}

\author{
Bodo Haas $^{1 *}$, Paul Schlinkert ${ }^{2}$, Peter Mayer ${ }^{1}$ and Niels Eckstein ${ }^{1}$
}

\begin{abstract}
Two different types of adipose tissues can be found in humans enabling them to respond to starvation and cold: white adipose tissue (WAT) is generally known and stores excess energy in the form of triacylglycerol (TG), insulates against cold, and serves as a mechanical cushion. Brown adipose tissue (BAT) helps newborns to cope with cold. BAT has the capacity to uncouple the mitochondrial respiratory chain, thereby generating heat rather than adenosine triphosphate (ATP). The previously widely held view was that BAT disappears rapidly after birth and is no longer present in adult humans. Using positron emission tomography (PET), however, it was recently shown that metabolically active BAT occurs in defined regions and scattered in WAT of the adult and possibly has an influence on whole-body energy homeostasis. In obese individuals adipose tissue is at the center of metabolic syndrome. Targeting of WAT by thiazolidinediones (TZDs), activators of peroxisome proliferator-activated receptor $y$ (PPARY) a 'master' regulator of fat cell biology, is a current therapy for the treatment of type 2 diabetes. Since its unique capacity to increase energy consumption of the body and to dissipate surplus energy as heat, BAT offers new perspectives as a therapeutic target for the treatment of obesity and associated diseases such as type 2 diabetes and metabolic syndrome. Recent discoveries of new signaling pathways of BAT development give rise to new therapeutic possibilities in order to influence BAT content and activity.

Keywords: 'Brite' adipocytes, Brown adipose tissue, Positron emission tomography, Thermogenesis, Transdifferentiation, UCP1, White adipose tissue
\end{abstract}

\section{White adipose tissue as drug target}

WAT is the largest lipid and energy storage in the human body. Excessive body fat, however, leads to insulin resistance, dyslipidaemia and type 2 diabetes. Over a long time it was believed that WAT is hormonally inert, but this paradigm is now obsolete. Today it is estimated, that the adipose organ is the largest endocrine organ of the human body [1]. Adipose tissue mainly produces and secretes cytokines such as adiponectin (encoded by the murine gene Adipoq), leptin (encoded by the murine gene Lep), resistin, tumor necrosis factor $\alpha(\mathrm{TNF} \alpha)$ and interleukins (ILs), which are referred to as adipokines according to their site of secretion [2]. In healthy (lean) subjects, adiponectin has a positive insulin sensitizing effect on other tissues [3]. Leptin is secreted by adipocytes and suppresses appetite by binding to leptin receptors in the central nervous system (CNS) [4]. In obesity, however, different adipokines take over control. Among

\footnotetext{
* Correspondence: bodo.haas@bfarm.de

${ }^{1}$ Federal Institute for Drugs and Medical Devices, Kurt-Georg-Kiesinger-Allee 3, Bonn 53175, Germany

Full list of author information is available at the end of the article
}

others, resistin, IL-1, IL-6, and TNF $\alpha$ are secreted from adipocytes, fibroblasts, macrophages and monocytes which reside in adipose tissue. These adipokines are described to be involved in mediating insulin resistance in peripheral tissues and to increase the risk for type 2 diabetes [5-8]. Excess adiposity is not only associated with a dysregulation in adipokine profile, but also with an increased portal release of free fatty acids (FFA). The high concentrations of FFA decrease the hepatic degradation of apolipoprotein B and insulin, which may contribute to the dyslipidemia, hyperinsulinemia, and insulin resistance observed in visceral obesity [9].

A current pharmacological approach to counteract insulin resistance and type 2 diabetes is the use of thiazolidinediones (TZDs), which are agonists on peroxisome proliferator-activated receptor $\gamma$ (PPAR $\gamma)$. TZDs promote differentiation of preadipocytes into white adipocytes [10] and are assumed to redirect FFA away from skeletal muscle towards adipose tissue (the so-called lipid steal hypothesis) [11,12]. TZDs are also implicated in positively influencing insulin resistance by decreasing the expression of TNF $\alpha$, IL-1, and resistin while
C Biomed Central

(c) 2012 Haas et al.; licensee BioMed Central Ltd. This is an Open Access article distributed under the terms of the Creative Commons Attribution License (http://creativecommons.org/licenses/by/2.0), which permits unrestricted use, distribution, and reproduction in any medium, provided the original work is properly cited. 
increasing the production of adiponectin [2,13]. A drawback of this therapeutic approach is weight gain caused by the accumulation of differentiated adipocytes, fluid retention, and an increased risk of cardiovascular events. These side effects are probably caused by the classical agonist action of TZDs. Choi et al. [14] have currently described a differential regulation of PPAR $\gamma$. Ligands which prevent the high-fat diet (TNF $\alpha)$-induced phosphorylation of Ser 273 of PPARY by CDK5 and only have minimal agonist activity still retain a potent anti-diabetic effect $[14,15]$. Phosphorylation of PPAR $\gamma$ by CDK5 does not change its transcriptional activity per se but changes the expression of specific genes (e.g. reduction in Adipoq expression) (Figure 1).

Promising partial PPAR $\gamma$ agonists such as NS-1 (5Z)-5[4-hydroxy-3-methoxy-phenyl) methylene] thiazolidine-2, 4-dione) or balaglitazone are currently investigated $[16,17]$. NS-1 induced adipogenesis in vitro to a 25 fold lesser extent than pioglitazone and improved hyperglycemia and insulin resistance in diet-induced obesity mice without significant weight gain. Balaglitazone already underwent phase III clinical trials and showed significant improvement in glucose handling and hemoglobin A1c (HbA1c) levels comparable to pioglitazone. Importantly, side effects like fluid retention and fat accumulation were less pronounced in the balaglitazone groups [18]. Thus, identification of 'partial' PPAR $\gamma$ agonists which prevent phosphorylation of Ser 273 but do not show classical agonist action might lead to more specific therapies reducing the emergence of side effects [14].

Another class of antidiabetic drugs, the sulfonylureas, which stimulate insulin secretion by blocking ATPdependent potassium channels of pancreatic $\beta$-cells, have also been implicated to act on human white adipocytes. It has been demonstrated that glimeperide and glibencalmide induce the differentiation of human white preadipocytes and suppress cytokine expression probably by activation of PPAR $\gamma$ [19].

Another approach to target adipocytes is to increase lipolysis. Lipolysis in adipocytes is mediated by norepinephrin (NE) [20]. NE binds to $\beta$-adrenoceptors ( $\beta$-ARs), which are highly abundant on the surface of adipocytes, and thereby activates adenylate cyclase (AC) which increases intracellular cAMP levels. As a consequence hormone-sensitive lipase (HSL) and perilipin are phosphorylated by PKA leading to the release of FFA. However, FFA themselves could increase insulin resistance, as mentioned above. This process is tightly regulated by the cGMP-inhibited phosphodiesterase 3B (PDE3B), which is expressed in white and brown adipocytes. Activation of PDE3B leads to increased hydrolysis of cAMP and thereby inhibition of catecholamineinduced lipolysis, reduction in insulin-induced glucose uptake, and lipogenesis (reviewed in [21]). Using the

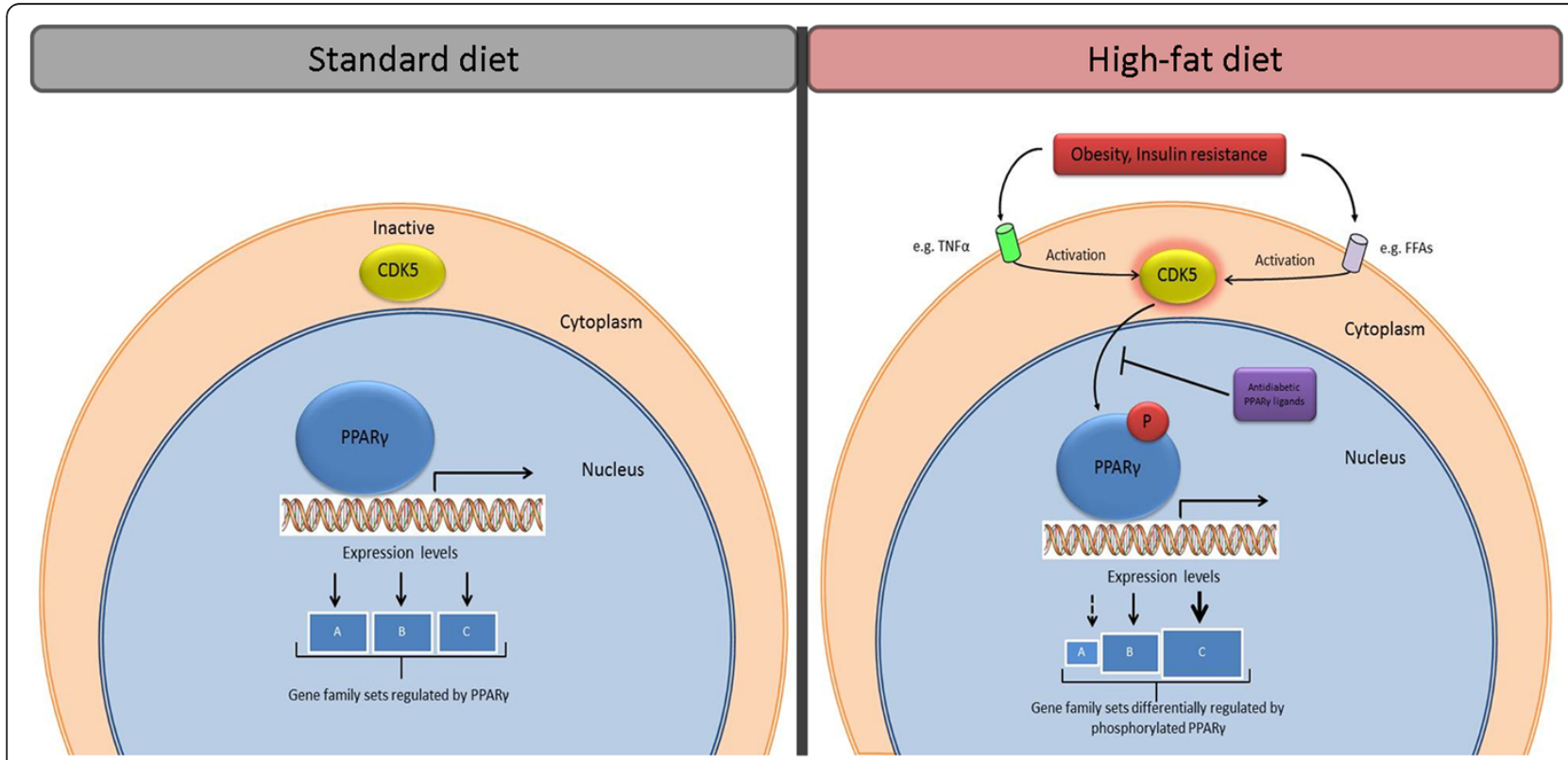

Figure 1 Regulation of PPARy activity in conditions of a standard diet (lean, insulin-sensitive state) compared to a high-fat diet (obese, insulin-resistant state) in WAT of mice. The activity of PPARY is differentially regulated during standard diet (left) and high-fat diet (right) conditions. Obesity and insulin resistance, both a result of a high-fat diet, lead to the production of inflammatory cytokines, such as TNFa. Both FFA and TNFa can activate CDK5, which in turn phosphorylates serine 273 on PPARy thereby inducing the expression of different gene family sets compared to unphosphorylated PPARY. Differential induction and repression of gene sets are represented by A, B, and C. Furthermore, some PPARy ligands block the phosphorylation of PPARY by CDK5, which may result in the expression of the same gene family as under a normal diet. Abbreviations: CDK5, cyclindependent kinase 5; FFA, free fatty acids; PPARY, peroxisome proliferator-activated receptor $\gamma$; TNFa, tumor necrosis factor a. 
PDE3 inhibitor amrinone it could be shown that insulin's antilipolytic effect on human adipose tissue in vivo is mediated by stimulation of PDE3 [22]. Targeted-inhibition of $\mathrm{PDE} 3 \mathrm{~B}$ in conjunction with a $\beta$-AR agonist could therefore be a promising approach to increase intracellular cAMP levels in adipocytes. However, to date it is not known whether this approach is feasible due to the release of FFA. Furthermore, $\beta$-AR agonists and PDE inhibitors could have cardiovascular side effects.

\section{Brown adipose tissue physiology}

In contrast to WAT, brown adipose tissue (BAT) combusts energy and releases heat. This unique function allows newborns to maintain body temperature in cold environments (non-shivering thermogenesis). BAT and WAT differ not only at the functional but also on the morphological and molecular levels. White adipocytes are usually large, round cells with a diameter that varies from 25-200 micrometer, and contain a large unilocular lipid droplet surrounded by a thin layer of cytoplasm with few mitochondria. The nucleus is flattened and located on the periphery. In contrast, brown adipocytes are cells with polygonal shape, normal cytoplasm with multilocular lipid droplets, and the nucleus is located centrally. Their brown color is due to the large quantity of mitochondria exhibiting numerous cristae. The main biological function of brown adipocytes is thermogenesis; energy storage in the form of lipids takes place but to a lesser extent to that of white adipocytes [23].

In infants, BAT is mainly localized in the neck, supraclavicular, in the axillae, and peri-/suprarenal. After birth BAT content is high accounting for $2-5 \%$ of body weight but gradually decreases during the first years [24,25].

The ability to generate heat (thermogenic capacity) results from a protein referred to as uncoupling protein 1 (UCP1) [26]. It is found exclusively in brown adipocytes, where it ensures uncoupling of the mitochondrial respiratory chain. UCP1 forms a pore in the inner mitochondrial membrane, leading to the break-down of the electrochemical proton gradient (proton leak), which is required for the activation of ATP synthesis in the mitochondrial matrix. As a result, ATP synthesis is blunt and excess energy is released as heat. UCP1 is activated among others by FFA and thus its activity is directly coupled to lipolysis. Cold stimuli lead to activation of the sympathetic nervous system (SNS) and the release of $\mathrm{NE}$ at the sympathetic nerve terminals, which profusely innervate the BAT. NE binds to $\beta_{3}$-ARs, which are highly abundant on the surface of brown adipocytes, and activates lipolysis. The subsequent release of FFA activates UCP1. Additionally, NE increases mitochondrial biogenesis and the expression of $U c p 1$ via activation of p38 mitogen-activated protein kinase (p38MAPK) and
PPAR $\gamma$ coactivator $1 \alpha(\mathrm{PGC} 1 \alpha)$ [27]. Thus, prolonged cold exposure triggers brown adipocytes to produce more heat. Brown adipocytes can sufficiently provide themselves with lipids as they express insulin receptors and glucose transporters and thus are able to take up larger amounts of glucose, a substrate for lipogenesis. The insulin pathway is crucial for the regulation of adipogenesis, Ucp1 expression, and mitochondrial biogenesis [28]. Insulin can further affect thermogenesis by increasing substrate uptake by BAT and increasing sympathetic activity mediated by the hypothalamus [29]. These factors may be connected to the thermic effect of food [30]. In experiments with brown adipocytes derived from mice it was demonstrated that nitric oxide (NO) and cyclic guanosine monophosphate (cGMP) can increase Ucp1 expression and mitochondrial biogenesis via protein kinase G (PKG). Simultaneously, the activated cGMP pathway increases the differentiation of preadipocytes into mature brown adipocytes by interfering with the RhoA/ROCK and insulin signaling pathways [31,32]. Also regulation of the cGMP cascade in BAT and WAT has recently been shown for natriuretic peptides (NPs) via the NP receptor A (NPRA) and the NP clearance receptor (NPRC) [33]. In contrast, Becerril et al. [34] demonstrated, that inducible NO synthase (iNOS)knockout mice showed an increased expression of genes involved in brown adipocyte function (Pgc1a, Ucp1, and Ucp3) and brown adipogenesis (Prdm16 and Bmp7). Moreover, deletion of the iNOS gene improves the brown-like phenotype and the molecular function of brown fat in Lep-deficient obese $(o b / o b)$ mice, which is characterized by a "white-like" appearance of BAT. Thus, further studies are needed to disentangle the role of $\mathrm{NO}$ in the physiology of BAT.

Brown adipocyte function is further regulated by thyroid hormones because they express high amounts of thyroid hormone receptors and the enzyme deiodinase type 2 (D2, encoded by the murine gene Dio2), which converts thyroxine (T4) into the more potent triiodothyronine (T3). T3 promotes mitochondrial biogenesis, induces the expression of $U c p 1$, and increases the activity of brown adipocytes [35,36]. Expression and activity of D2 can be triggered by cAMP. Bile acids can mediate cAMP-dependent D2 activation via the G-proteincoupled receptor TGR5 in brown adipocytes leading to an increase in energy expenditure [37] (Figure 2).

Thermogenesis and BAT activity is under tight control of the CNS. BAT is innervated by distinct nuclei of the hypothalamus, which coordinates signals from temperature changes and food intake [38]. A crucial role in hypothalamic regulation of sympathetic outflow and BAT thermogenesis plays AMP-activated protein kinase (AMPK). The inhibition of AMPK by leptin in the hypothalamus is an important mechanism in the regulation 
of food intake and energy homeostasis. Protein tyrosin phosphatase 1B (PTP1B) has been implicated in interfering with leptin signaling in the hypothalamus [39]. Using neuronal Ptb1b knock-out mice, Xue et al. [40] demonstrated that absence of $P t b 1 b$ in the hypothalamus results in increased leptin signaling and augmented inhibition of hypothalamic AMPK. As a consequence neuronal signaling to BAT is altered leading to increased AMPK activity in BAT with increased uncoupling and mitochondrial biogenesis. Inhibition of AMPK by central administration of $\mathrm{T} 3$ to rats leads to reduced body weight without altering food intake due to increased SNS activity and upregulation of thermogenic markers in BAT. Importantly, administration of T3 to a single nucleus of the hypothalamus could entirely replicate effects on BAT achieved with peripherally applied T3 in higher doses [41]. Currently, bone morphogenic protein 8B (BMP8B) has, besides its effect on brown adipocytes, also been described to have central effects on BAT. $B m p 8 b^{-/-}$mice display altered neuropeptide levels and reduced phosphorylation of hypothalamic AMPK. Central BMP8B treatment resulted in increased thermogenesis in BAT via neuronal activation of regulatory nuclei in the hypothalamus [42].

\section{BAT in adult humans}

In the last decade it could be demonstrated by using positron emission tomography (PET) that adult humans also possess metabolically active BAT [43-46]. Originally, PET was used in conjunction with computer tomography $(\mathrm{CT})$ to image tumors and metastases [47]. Tumor tissues have a higher metabolic activity and thus take

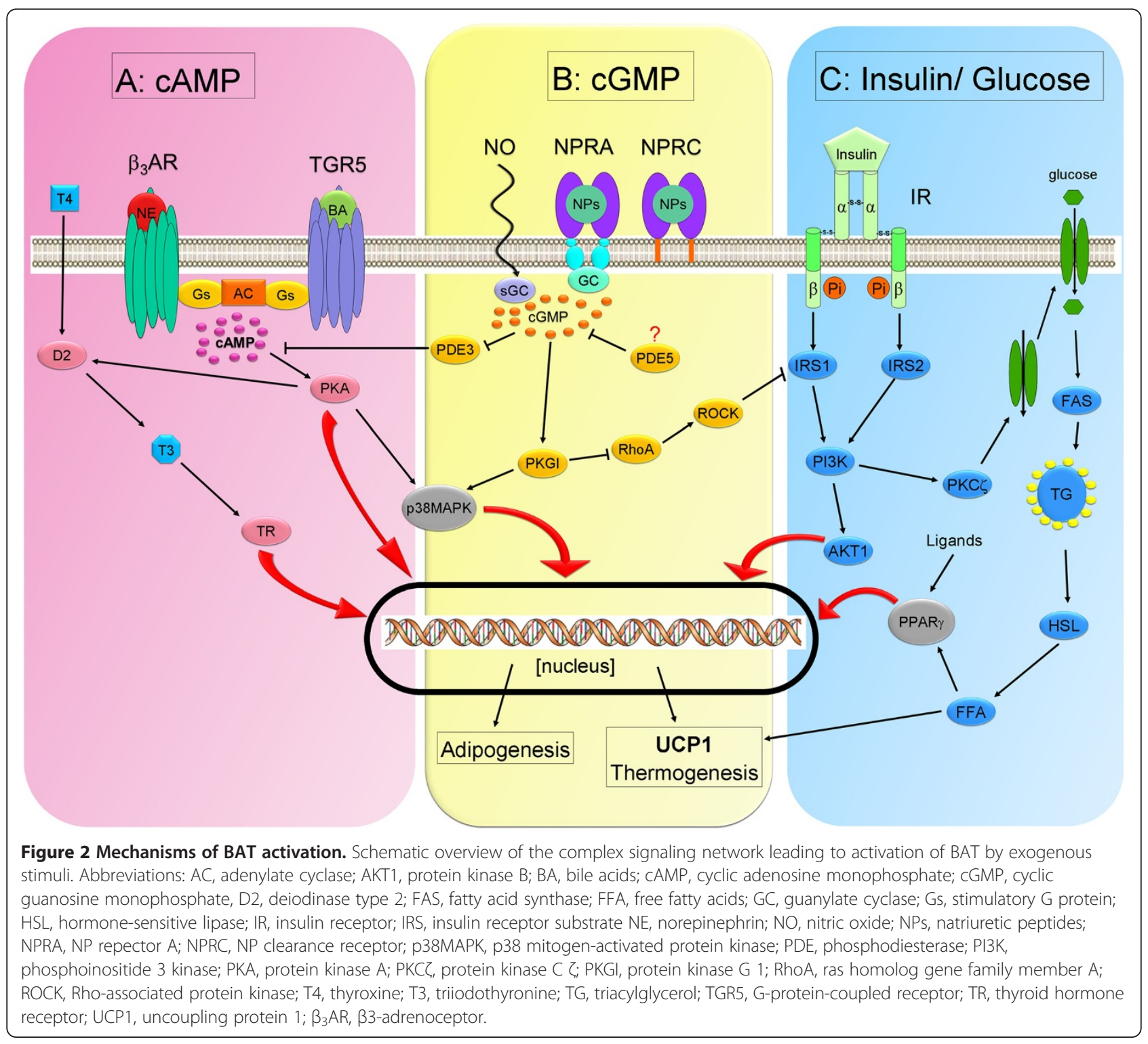


up more glucose, a phenomenon which is referred to as the Warburg effect. Cancer patients injected with radioactively labeled glucose (2-deoxy- $2\left[{ }^{18} \mathrm{~F}\right]$ fluoro-Dglucose, FDG), take up FDG in tumor tissue by sodiumindependent glucose transporters (e.g. GLUT1, GLUT3 and GLUT4). After passing the initial phase of glucose metabolism and phosphorylation by hexokinase to the 6-phosphate form, FDG does not enter the Krebs cycle and is trapped in the cell. This results in a strong signal of tumor tissues in the PETscan. It was noted that in some PET scans other regions also showed a symmetrical, high FDG uptake, especially around the collar bone (supraclavicular), the mediastinum (para-aortic), along the spinal column (paravertebral), and in the kidneys (supra-/perirenal) $[47,48]$. After the combination of PET with CT (PET-CT), it soon became clear that the unusual pattern is not caused by muscles, but rather by a tissue with a lower density such as adipose tissue. White fat depots, however, show only marginal glucose uptake and hardly give a signal in PET-CT. It took a rather long time until it was concluded that the observed signals are BAT [48]. Additionally, subjects who were exposed to cold prior to PET scans, show an even stronger FDG uptake in BAT $[45,49]$. However, $\beta$-AR antagonists such as propranolol $(\sim 1 \mathrm{mg} / \mathrm{kg})$ reduce FDG uptake [50,51]. Studies of biopsies from the supraclavicular region in 2009 finally provided clear proof that the excised tissue is BAT $[46,52]$. The expression of specific genes such as UCP1 was shown first, followed by the histological examination, which showed the presence of multilocular lipid droplets, an unequivocal characteristic of BAT.

\section{Lineage development of white and brown adipocytes}

Adipocytes derive from multipotent mesenchymal stem cells (MSCs), which emerge from the mesoderm of the embryo. White adipocytes differentiate from pericytes, which derive from the lateral mesoderm [53]. In the course of development adipoblasts (precursor cells) are derived from the MSCs which further develop into preadipocytes. Preadipocytes finally are able to differentiate into mature white adipocytes. A similar course was proposed for the development of brown adipocytes. Surprisingly, it has recently been found that brown adipocytes carry the genetic signature of a muscle cell. Muscle precursor cells derive from the paraxial mesoderm and express the gene $M y f 5$. They can develop into both skeletal muscle cells and brown adipocytes [54,55]. A driving factor inducing the differentiation of progenitors (Myf5positiv and -negativ) into brown adipocytes via the activation of transcription factors such as PR domain containing 16 (PRDM16), CCAAT/enhancer-binding protein $\beta(\mathrm{C} / \mathrm{EBP} \beta)$, and $\mathrm{PGC} 1 \alpha$ is the cytokine BMP7, which belongs to the TGF $\beta$ superfamily $[56,57]$. It has been shown in lineage tracing studies that the interscapular and perirenal BAT depots of mice are derived from Myf5-positive muscle precursor cells. However, brown adipocytes can also appear in WAT and muscle tissue without carrying the $M y f 5$ signature, for example, after chronic cold exposure or $\beta$-adrenergic stimulation [58]. Both, transdifferentiation of white adipocytes into brown adipocytes ('brown in white' so called 'brite' or 'beige' adipocytes) and the occurrence of specific precursors of brown adipocytes in WAT are currently discussed (Figure 3). In a very recent publication by $\mathrm{Wu}$ et al. [59] it was demonstrated that 'brite' adipocytes have extremely low basal expression of Ucp1, but, like classical brown adipocytes, they respond to cAMP stimulation with high $U c p 1$ expression and respiration rates. Data from UCP1 expression studies suggest that a lean adult possesses one brown adipocyte scattered in 100-200 white adipocytes of visceral adipose tissue [60]. In a recent publication by Vegiopoulus et al. [61] cyclooxygenase 2 (COX2) activity and prostaglandines (PGs) have been implicated as downstream effectors of $\beta$-adrenergic signaling in WAT, which shift progenitor cells towards a brown adipocyte phenotype. Boström et al. [62] have shown that PGC-1 $\alpha$ stimulated the expression of several muscle gene products such as the newly identified type I membrane protein irisin (encoded by the murine gene Fndc5), which was found in mouse and human plasma and is secreted after exercise. Overexpession of Fndc5 in mice resulted in 3-4 fold increase of irisin plasma levels and induced browning of subcutaneous fat and thermogenesis. Moderately increased irisin expression in high-fat diet-treated obese and insulin-resistant mice resulted in reduction of body weight and improvement of diet-induced insulin resistance. Moreover, 'brite' adipocytes have been shown to be preferentially sensitive to irisin [59].

In another study by Ohno et al. [63] it has been shown that PPAR $\gamma$ agonists like rosiglitazone induce the browning of subcutaneous white adipose tissue through stabilization of the PRDM16 protein. NPs through NPRA, cGMP, and PKG can activate p38 $\alpha$ MAPK to increase mitochondrial biogenesis and uncouple respiration in human white adipocytes. It has also been demonstrated that atrial NP and $\beta$-AR agonists can act together in an additive manner to more robustly promote brown adipocyte features and functions in human white adipocytes [33]. In this context it is noteworthy that expression of Pde5 has been described in white adipocytes $[64,65]$. Inhibition of PDE5 with sildenafil triggered the differentiation of white preadipocytes [66]. Therefore, PDE5 blockade in adipose tissue should lead to increasing intracellular cGMP levels and could also have an impact on brown adipocyte differentiation and browning of WAT. This hypothesis is further 


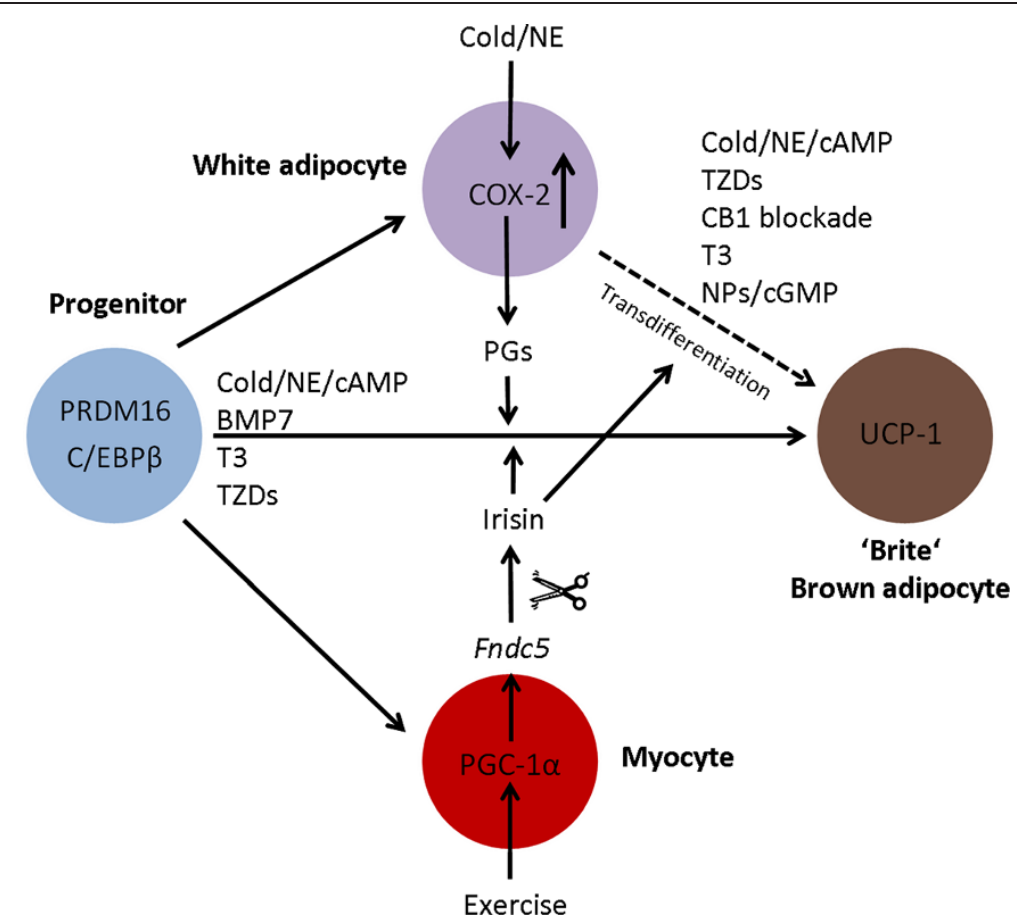

Figure 3 Control of 'brite' (brown) adipocyte development. The scheme depicts the interplay of white adipocytes, myocytes, and mesenchymal precursor cells involved in the (trans-) differentiation process of 'brite' and/or brown adipocytes. Abbreviations: BMP7, bone morphogenic protein 7; CAMP, cyclic adenosine monophosphate; CB1, cannabinoid type 1 receptor; C/EBP $\beta$, CCAAT/enhancer binding protein $\beta$; cGMP, cyclic guanosine monophosphate; COX2, cyclooxygenase 2; Fndc5, fibronectin type III domain containing 5; NE, norepinephrin; NPs, natriuretic peptides; PGs, prostaglandines; PGC1a, PPARY-coactivator 1a; PRDM16, PR domain containing 16; T3, triiodothyronine; TZDs, thiazolidinediones; UCP1, uncoupling protein 1.

strengthened by the finding that PDE5 inhibition with vardenafil in human WAT explants resulted in a marked increase in PPARG and PGC1A expression paired with an increase in mitochondrial DNA content [67]. However, data on Pde5 expression in brown adipocytes are still lacking (reviewed in [68]). Blockade of cannabinoid type 1 receptor (CB1) with rimonabant, a selective antagonist of the CB1 receptor expressed on white adipocytes, induces transdifferentiation of differentiated murine white adipocytes towards a brown fat phenotype [69]. In addition to its function on BAT, T3 has also been implicated in the induction of brown-like adipocytes in WAT [70] (Figure 3).

\section{Physiological relevance of BAT in adults}

The emerging question however is whether BAT in adults plays an essential physiological role. A retrospective analysis of studies with PET and PET-CT scans showed that under normal conditions BAT was only detected in about $10 \%$ of the examined adults $[43,48]$. However, histological analysis of biopsies revealed an approximately three times higher abundance [52]. Prospective studies, where young people were exposed to cold, concluded that $96 \%$ of the subjects showed functional BAT [45]. The controversy of these results is probably related to the inaccuracy of the PET-CT imaging technology. In addition, various factors such as ambient temperature, food intake or intake of FFA and the use of $\beta$-AR antagonists [50,51] can affect FDG uptake of the cells, which was not taken into account in any of the studies. The fact that BAT content decreases with age while usually WAT content increases with age, suggests, that BAT may play a role in whole-body energy homeostasis. In most studies, an inverse correlation of body mass index (BMI) and incidence of BAT and its activity were detected. From a bioenergetic perspective when activated (e.g. by cold exposure) BAT takes up about as much glucose as the brain, which is beside muscles, the main glucose consumer of the body. In an older review from the 1980s Stock and Rothwell [71] already calculated that "as little as $80-100 \mathrm{~g}$ of brown fat, producing heat at half its maximal capacity, could account for approximately $20 \%$ of a $70 \mathrm{~kg}$ man's daily energy expenditure. Thus, this almost insignificant mass of tissue could make all the difference between him maintaining weight or gainig up to $20 \mathrm{~kg}$ per year." More recent studies propose more moderate assumptions: In a PET-CT scan of a subject $63 \mathrm{~g}$ of supraclavicular BAT were detected. The authors concluded that if this deposit was fully activated over a year, it would burn energy 
equivalent to the energy content of about $4 \mathrm{~kg}$ of adipose tissue and thus would contribute substantially to energy expenditure [46]. Using a new approach by also measuring nonesterified fatty acid (NEFA) uptake upon cold exposure it could be shown that all subjects displayed substantial glucose and NEFA uptake in BAT [72]. An increase of $80 \%$ total energy expenditure was observed during 3 hours of cold exposure and it is likely that a big portion was mediated by BAT thermogenesis. The authors calculated that mobilization of $28 \mathrm{~g}$ of BAT lipid reserve would be sufficient to account for the extra energy of roundabout $250 \mathrm{kcal}$ expended. Taken together, these studies demonstrate that BAT is undoubtedly involved in non-shivering thermogenesis in adults. As main sources of energy for this process BAT consumes intracellular TG and glucose. However, it remains to be determined whether frequent and chronic cold exposure leads to relevant energy expenditure or if compensatory mechanisms such as increased appetite might countervail this effect.

\section{Activation of BAT development and activity by drugs} Improvement of the imaging technology is essential to further identify (scattered) depots of BAT and measure its impact on energy expenditure for the treatment of obesity. A new approach has been reported by Chen et al. [73], which demonstrated the feasibility of measuring BAT volume and function in vivo by using magnetic resonance imaging in rats. Nevertheless, it is not clear yet whether human adults have sufficient BAT (or its precursor cells), which could be activated to have a significant long lasting effect on energy expenditure. Despite all uncertainties BAT appears to be a promising pharmacological target for the treatment of obesity and associated diseases like type 2 diabetes. Experiments in rats and mice give cause for hope that in humans the activation of specific signaling pathways in BAT can increase its development and activity and thus accelerate energy expenditure (extensively reviewed in [74]). Several approaches are possible (see also Table 1 for drug substances currently under investigation):

- Cold exposure is the physiological way to increase BAT development and its activity. For example, increased BAT has been described for outdoor workers from Northern Europe [75]. However, various questions remain to be answered. At what temperatures BAT is fully activated? How long and often cold exposure needs to be to achieve notable effects on energy expenditure? Van Marken Lichtenbelt [45] for instance reported measurable BAT activity already after mild cold exposure of $16^{\circ} \mathrm{C}$ for 2 hours and Saito et al. [49] described substantial FDG uptake into BAT after exposure of subjects to $19^{\circ} \mathrm{C}$ for 2 hours. A significant increase of BAT thermogenesis and energy expenditure has very recently been described after only 3 hours of cold exposure to $18^{\circ} \mathrm{C}$ [72]. Short term exposure to lower temperatures and chronic cold exposure and is influence on BAT activity will have to be determined in future studies.

- Mimicking cold exposure by pharmacological activation of BAT with sympathomimetics avoids cold exposure of patients probably resulting in higher rates of compliance. $\beta_{3}$-AR agonists are currently under development and show good results on energy expenditure in rodents. However, clinical trials in humans so far did not provide the expected

Table 1 Possible treatments directly targeting WAT and/or BAT in obesity and type 2 diabetes

\begin{tabular}{|c|c|c|c|c|}
\hline Drug & Effect & Mechanism of action & Target organ & Class \\
\hline BMP7 (OP-1 $\left.{ }^{\mathrm{TM}}\right)$ & BAT activation & Developmental regulator & BAT & Cytokine \\
\hline BMP8B & BAT activation & Developmental regulator & BAT, CNS & \\
\hline Sildenafil, vardenafil & WAT (trans-) differentiation, (BAT activation) & PDE5 inhibition & WAT, (BAT) & $\begin{array}{l}\text { Enzyme } \\
\text { inhibitor }\end{array}$ \\
\hline Amrinone & WAT lipolysis, (WAT transdifferentiation, BAT activation) & PDE3 inhibition & WAT, (BAT) & \\
\hline$\overline{G C-1, K B-141}$ & BAT activation, (WAT transdifferentiation) & $\begin{array}{l}\text { Thyroid hormone } \\
\text { mimetics }\end{array}$ & BAT & Hormone \\
\hline T3 & BAT activation, (WAT transdifferentiation) & Thyroid hormone & BAT, CNS & \\
\hline BRL-26830, L-796568, N-5984 & BAT activation, WAT transdifferentiation, lipolysis & $\begin{array}{l}\text { selective } \beta_{3}-A R \\
\text { agonist }\end{array}$ & BAT, WAT & $\begin{array}{l}\text { Receptor } \\
\text { agonist }\end{array}$ \\
\hline Bile acids (endogenous ligands) & BAT activation & TGR5 receptor agonist & BAT & \\
\hline ANP, BNP (endogenous ligands) & BAT activation, WAT transdifferentiation & NPRA agonsit & BAT, WAT & \\
\hline Rimonabant & WAT transdifferentiation & CB1 antagonist & WAT, CNS & $\begin{array}{l}\text { Receptor } \\
\text { antagonist }\end{array}$ \\
\hline $\begin{array}{l}\text { TZDs, NS-1, balaglitazone, MRL-24, } \\
\text { (Sulfonylureas) }\end{array}$ & WAT (trans-) differentiation, BAT activation & $\begin{array}{l}\text { (partial) activation } \\
\text { of PPARY }\end{array}$ & WAT, BAT & $\begin{array}{l}\text { Transcription } \\
\text { factor ligand }\end{array}$ \\
\hline
\end{tabular}


results, which may be due to different binding characteristics of the human and the rodent $\beta_{3}$-ARs [76,77]. Selective thyroid hormone mimetics such as GC-1 and KB-141 with reduced activity on heart and muscle promote weight loss in rodents [78,79]. Targeting of the bile acid receptor TGR5 expressed in BAT leads to an increase in energy expenditure via D2 activation. Currently, various ligands on TGR5 are under investigation [73]. Substances that activate the cGMP-signaling pathway (e.g. NPs, PDE5 inhibitors) are further examples of promising substances.

- Activating residing brown fat progenitors in skeletal muscle and WAT is another approach which could be envisioned. Among others, a cytokine in focus is BMP7. BMP7 $\left(\mathrm{OP}-1^{\mathrm{TM}}\right)$ is therapeutically used in the U.S. for the induction of bone growth and osteoporosis treatment. Recently, it has been shown that BMP7 regulates the differentiation of precursor cells into brown adipocytes. Bmp7-transgenic mice develop more BAT and have increased energy expenditure and reduced weight gain [57]. Manipulation of COX2-induced PG signaling of BAT progenitors localized in WAT represents an alternative strategy for enhancing BAT activity that could help protecting against energy surplus and body weight gain [61].

- Transdifferentiation of white adipocytes into 'brite' adipocytes: Agonists of the transcription factor PPAR $\gamma$, such as the TZDs rosiglitazone or pioglitazone, increase the expression of brown fatspecific proteins (e.g. PGC1 $\alpha$ and UCP1) both in fat cell lines and in white adipose tissue from mice $[80,81]$. Also a potential to trigger transdifferentiation of white adipocytes towards a brown fat phenotype via the stabilization of the PRDM16 protein has been proposed for TZDs [63]. PPARy agonists probably increase the metabolic rate by stimulating BAT activity and increase whole body BAT content. However, people with type 2 diabetes treated with pioglitazone at $45 \mathrm{mg} / \mathrm{d}$ for 24 weeks showed no changes in their metabolic rate, gained weight, and suffered from fluid retention [82]. The CB1 antagonist rimonabant acts on white adipocytes and leads to a transdifferentiation towards a brown fat phenotype in vitro. Patients treated with rimonabant show weight loss and improved glucose homeostasis (RIO study $[83,84]$ ) what might be explained by increased thermogenesis, however, central effects are probably also involved. In 2006 the European Medicines Agency (EMA) recommended the approval of rimonabant, the first drug of this class, as an adjunct to diet and exercise in treating obesity. However, in October 2008, EMA recommended the suspension of rimonabant because of its psychiatric side effects [85]. The NPRA has been implicated in the transdifferentiation process of human white adipocytes in vitro and in mouse models in vivo. Targeting NPRs (or subsequent cGMP signaling) is a promising new approach. Inhibition of PDE5 might by a strategy to interfere with cGMP signaling, however, no human data are available so far.

- Also an ex vivo approach seems feasible. Progenitor cells can be isolated from liposuctions or muscle biopsies of an obese donor. These cells can be induced to differentiate in vitro into brown adipocytes by treatment with BMP7 or overexpression of PRDM16 or PGC1A.

Differentiated brown adipocytes can be transplanted back to the donor where they develop into functional BAT. This approach yielded remarkable results when tested in mice [56].

- Targeting the CNS e.g. the leptin signaling pathways in the hypothalamus might produce SNS effects specific to BAT. In rodents central application of T3 or BMP8B to hypothalamic nuclei resulted in BAT activation by modulation of hypothalamic regulatory circuits $[41,42]$.

\section{Conclusions}

Direct targeting of adipose tissue is still far from being a magic bullet for the treatment of obesity and type 2 diabetes. However, new options arise by targeting BAT to increase energy expenditure. Nevertheless, several questions remain to be answered before targeting of BAT as therapeutic option becomes possible. It is still not clear if chronic BAT activation leads to sufficient energy expenditure to achieve the therapeutic goal of weight loss. Furthermore, it is not known if compensatory mechanisms such as increased appetite might countervail increased energy expenditure. Well-directed cold exposure appears to be the most physiological stimulus to activate BAT. Optimum conditions for a targeted cold exposure of an anticipated "cold-therapy" need to be further elucidated. A pharmacological and cell-based therapy approach seems plausible and many druggable targets could be identified so far. On the other hand, many safety concerns remain, requiring the need for the identification of new drug targets and substances in line with a careful benefit-risk assessment.

\section{Abbreviations}

AC: adenylate cyclase; AKT1: protein kinase B; AMPK: AMP-activated protein kinase; ATP: adenosine triphosphate; BA: bile acids; BAT: brown adipose tissue; BMI: body mass index; BMP: bone morphogenic protein; C/ EBPB: CCAAT/enhancer binding protein $\beta$; CAMP: cyclic adenosine monophosphate; CB1: cannabinoid type 1 receptor; CDK5: cyclin-dependent kinase 5; CGMP: cyclic guanosine monophosphate; CNS: central nervous system; COX2: cyclooxygenase 2; CT: computer tomography; D2: deiodinase 
type 2; EMA: European Medicines Agency; FAS: fatty acid synthase; FDG: 2deoxy- $2\left[{ }^{18}\right.$ F]fluoro-D-glucose; FFA: free fatty acids; Fndc5: fibronectin type III domain containing 5; GC: guanylate cyclase; GLUT: glucose transporter; HBA1c: hemoglobin A1c; HSL: hormone-sensitive lipase; IL: interleukin iNOS: inducible NO synthase; IR: insulin receptor; IRS: insulin receptor substrate; MAPK: mitogen-activated protein kinase; MSCs: mesenchymal stem cells; NE: norepinephrin; NEFA: nonesterified fatty acid; NO: nitric oxide; NPRA: NP receptor A; NPRC: NP clearance receptor; NPs: natriuretic peptides; p38MAPK: p38 mitogen-activated protein kinase; PDE: phosphodiesterase; PET: positron emission tomography; PGC1a: PPARY coactivator 1a; PGs: prostaglandines; PI3K: phospoinositide 3 kinase; PKA: protein kinase A; PKCZ: protein kinase $C \zeta$; PKG: protein kinase G; PPARY: peroxisome proliferator-activated receptor $\gamma_{\text {; }}$ PRDM16: PR domain containing 16; PTP1B: protein tyrosin phosphatase 1B; RhoA: ras homolog gene family member A; ROCK: rho-associated protein kinase; SNS: sympathetic nervous system; T3: triiodothyronine; T4: thyroxine; TG: triacylglycerol; TGR5: Gprotein-coupled receptor 5; TNFa: tumor necrosis factor a; TR: thyroid hormone receptor; TZDs: thiazolidinediones; UCP1: uncoupling protein 1; WAT: white adipose tissue; $\beta$-AR: $\beta$-adrenoceptor.

\section{Competing interests}

The authors declare no financial conflict of interest.

\section{Authors' contributions}

$\mathrm{BH}$ wrote the manuscript and prepared figures, PS reviewed the manuscript and prepared figures, PM reviewed the manuscript, NE reviewed the manuscript. All authors read and approved the final manuscript.

\section{Acknowledgement}

This review article was supported by intramural funding of the Federal Institute for Drugs and Medical Devices, 53175 Bonn, Germany.

\section{Author details}

${ }^{1}$ Federal Institute for Drugs and Medical Devices, Kurt-Georg-Kiesinger-Allee 3, Bonn 53175, Germany. ${ }^{2}$ University of Salzburg, Molecular Biology, Hellbrunnerstraße 34, Salzburg 5020, Austria.

Received: 20 June 2012 Accepted: 23 October 2012

Published: 27 October 2012

\section{References}

1. Kershaw EE, Flier JS: Adipose tissue as an endocrine organ. J Clin Endocrinol Metab 2004, 89:2548-2556.

2. Trujillo ME, Scherer PE: Adipose tissue-derived factors: impact on health and disease. Endocr Rev 2006, 27:762-778.

3. Yamauchi T, Kamon J, Waki H, Terauchi Y, Kubota N, Hara K, Mori Y, Ide T, Murakami K, Tsuboyama-Kasaoka N, et al: The fat-derived hormone adiponectin reverses insulin resistance associated with both lipoatrophy and obesity. Nat Med 2001, 7:941-946.

4. Havel PJ: Control of energy homeostasis and insulin action by adipocyte hormones: leptin, acylation stimulating protein, and adiponectin. Curr Opin Lipidol 2002, 13:51-59.

5. Hotamisligil GS, Shargill NS, Spiegelman BM: Adipose expression of tumor necrosis factor-alpha: direct role in obesity-linked insulin resistance. Science 1993, 259:87-91.

6. Lagathu C, Yvan-Charvet L, Bastard JP, Maachi M, Quignard-Boulange A, Capeau J, Caron M: Long-term treatment with interleukin-1beta induces insulin resistance in murine and human adipocytes. Diabetologia 2006, 49:2162-2173.

7. Steppan CM, Bailey ST, Bhat S, Brown EJ, Banerjee RR, Wright CM, Patel HR, Ahima RS, Lazar MA: The hormone resistin links obesity to diabetes. Nature 2001, 409:307-312.

8. Spranger J, Kroke A, Mohlig M, Hoffmann K, Bergmann MM, Ristow M, Boeing H, Pfeiffer AF: Inflammatory cytokines and the risk to develop type 2 diabetes: results of the prospective population-based European Prospective Investigation into Cancer and Nutrition (EPIC)-Potsdam Study. Diabetes 2003, 52:812-817.

9. Rodriguez A, Catalan V, Gomez-Ambrosi J, Fruhbeck G: Visceral and subcutaneous adiposity: are both potential therapeutic targets for tackling the metabolic syndrome? Curr Pharm Des 2007, 13:2169-2175.
10. Funaki M: Saturated fatty acids and insulin resistance. J Med Invest 2009, 56:88-92.

11. Oakes ND, Thalen PG, Jacinto SM, Ljung B: Thiazolidinediones increase plasma-adipose tissue FFA exchange capacity and enhance insulinmediated control of systemic FFA availability. Diabetes 2001, 50:1158-1165.

12. Ye JM, Dzamko N, Cleasby ME, Hegarty BD, Furler SM, Cooney GJ, Kraegen EW: Direct demonstration of lipid sequestration as a mechanism by which rosiglitazone prevents fatty-acid-induced insulin resistance in the rat: comparison with metformin. Diabetologia 2004, 47:1306-1313.

13. Sharma AM, Staels B: Review: Peroxisome proliferator-activated receptor gamma and adipose tissue-understanding obesity-related changes in regulation of lipid and glucose metabolism. J Clin Endocrinol Metab 2007, 92:386-395.

14. Choi JH, Banks AS, Estall JL, Kajimura S, Bostrom P, Laznik D, Ruas JL, Chalmers MJ, Kamenecka TM, Bluher M, et al: Anti-diabetic drugs inhibit obesity-linked phosphorylation of PPARgamma by Cdk5. Nature 2010, 466:451-456.

15. Acton JJ III, Black RM, Jones AB, Moller DE, Colwell L, Doebber TW, MacNaul $\mathrm{KL}$, Berger J, Wood HB: Benzoyl 2-methyl indoles as selective PPARgamma modulators. Bioorg Med Chem Lett 2005, 15:357-362.

16. Chaudhary S, Dube A, Kothari V, Sachan N, Upasani CD: NS-1: A novel partial peroxisome proliferator-activated receptor gamma agonist to improve insulin sensitivity and metabolic profile. Eur J Pharmacol 2012, 684:154-160.

17. Agrawal R, Jain P, Dikshit SN: Balaglitazone: a second generation peroxisome proliferator-activated receptor (PPAR) gamma (gamma) agonist. Mini Rev Med Chem 2012, 12:87-97.

18. Henriksen $K$, Byrjalsen I, Qvist P, Beck-Nielsen H, Hansen G, Riis BJ, Perrild H, Svendsen OL, Gram J, Karsdal MA, et al: Efficacy and safety of the PPARgamma partial agonist balaglitazone compared with pioglitazone and placebo: a phase III, randomized, parallel-group study in patients with type 2 diabetes on stable insulin therapy. Diabetes Metab Res Rev 2011, 27:392-401.

19. Mayer P, Haas B, Celner J, Enzmann H, Pfeifer A: Glitazone-like action of glimepiride and glibenclamide in primary human adipocytes. Diabetes Obes Metab 2011, 13:791-799.

20. Van H, Lonnqvist F, Thorne A, Wennlund A, Large V, Reynisdottir S, Arner P Noradrenaline-induced lipolysis in isolated mesenteric, omental and subcutaneous adipocytes from obese subjects. Int J Obes Relat Metab Disord 1997, 21:972-979.

21. Degerman E, Ahmad F, Chung YW, Guirguis E, Omar B, Stenson L, Manganiello V: From PDE3B to the regulation of energy homeostasis. Curr Opin Pharmacol 2011, 11:676-682.

22. Enoksson $S$, Degerman E, Hagstrom-Toft E, Large V, Arner P: Various phosphodiesterase subtypes mediate the in vivo antilipolytic effect of insulin on adipose tissue and skeletal muscle in man. Diabetologia 1998, 41:560-568.

23. Fruhbeck G, Becerril S, Sainz N, Garrastachu P, Garcia-Velloso MJ: BAT: a new target for human obesity? Trends Pharmacol Sci 2009, 30:387-396.

24. Cannon B, Nedergaard J: Brown adipose tissue: function and physiological significance. Physiol Rev 2004, 84:277-359.

25. Gesta S, Tseng YH, Kahn CR: Developmental origin of fat: tracking obesity to its source. Cell 2007, 131:242-256.

26. Kozak LP, Harper ME: Mitochondrial uncoupling proteins in energy expenditure. Annu Rev Nutr 2000, 20:339-363.

27. Cao W, Daniel KW, Robidoux J, Puigserver P, Medvedev AV, Bai X, Floering $L M$, Spiegelman BM, Collins S: p38 mitogen-activated protein kinase is the central regulator of cyclic AMP-dependent transcription of the brown fat uncoupling protein 1 gene. Mol Cell Biol 2004, 24:3057-3067.

28. Valverde AM, Benito M, Lorenzo M: The brown adipose cell: a model for understanding the molecular mechanisms of insulin resistance. Acta Physiol Scand 2005, 183:59-73.

29. Ferrannini E, Galvan AQ, Gastaldelli A, Camastra S, Sironi AM, Toschi E, Bald S, Frascerra S, Monzani F, Antonelli A, et al: Insulin: new roles for an ancient hormone. Eur J Clin Invest 1999, 29:842-852.

30. Weyer C, Bogardus C, Mott DM, Pratley RE: The natural history of insulin secretory dysfunction and insulin resistance in the pathogenesis of type 2 diabetes mellitus. J Clin Invest 1999, 104:787-794.

31. Amieux PS, McKnight GS: Cyclic nucleotides converge on brown adipose tissue differentiation. Sci Signal 2010, 3:e2. 
32. Haas B, Mayer P, Jennissen $K$, Scholz D, Diaz MB, Bloch W, Herzig S, Fassler $R$, Pfeifer $A$ : Protein kinase $G$ controls brown fat cell differentiation and mitochondrial biogenesis. Sci Signal 2009, 2:ra78.

33. Bordicchia M, Liu D, Amri EZ, Ailhaud G, Dessi-Fulgheri P, Zhang C, Takahashi N, Sarzani R, Collins S: Cardiac natriuretic peptides act via p38 MAPK to induce the brown fat thermogenic program in mouse and human adipocytes. J Clin Invest 2012, 122:1022-1036.

34. Becerril S, Rodriguez A, Catalan V, Sainz N, Ramirez B, Collantes M, Penuelas I, Gomez-Ambrosi J, Fruhbeck G: Deletion of inducible nitric-oxide synthase in leptin-deficient mice improves brown adipose tissue function. PLoS One 2010, 5:e10962.

35. Golozoubova V, Gullberg H, Matthias A, Cannon B, Vennstrom B, Nedergaard J: Depressed thermogenesis but competent brown adipose tissue recruitment in mice devoid of all hormone-binding thyroid hormone receptors. Mol Endocrinol 2004, 18:384-401.

36. Silva JE: Thermogenic mechanisms and their hormonal regulation. Physiol Rev 2006, 86:435-464.

37. Watanabe M, Houten SM, Mataki C, Christoffolete MA, Kim BW, Sato H, Messaddeq N, Harney JW, Ezaki O, Kodama T, et al: Bile acids induce energy expenditure by promoting intracellular thyroid hormone activation. Nature 2006, 439:484-489.

38. Whittle AJ, Lopez M, Vidal-Puig A: Using brown adipose tissue to treat obesity - the central issue. Trends Mol Med 2011, 17:405-411.

39. Zabolotny JM, Bence-Hanulec KK, Stricker-Krongrad A, Haj F, Wang Y Minokoshi Y, Kim YB, Elmquist JK, Tartaglia LA, Kahn BB, et al: PTP1B regulates leptin signal transduction in vivo. Dev Cell 2002, 2:489-495.

40. Xue B, Pulinilkunnil T, Murano I, Bence KK, He H, Minokoshi Y, Asakura K, Lee A, Haj F, Furukawa N, et al: Neuronal protein tyrosine phosphatase 1B deficiency results in inhibition of hypothalamic AMPK and isoform-specific activation of AMPK in peripheral tissues. Mol Cell Biol 2009, 29:4563-4573.

41. Lopez M, Varela L, Vazquez MJ, Rodriguez-Cuenca S, Gonzalez CR, Velagapudi VR, Morgan DA, Schoenmakers E, Agassandian K, Lage R, et al: Hypothalamic AMPK and fatty acid metabolism mediate thyroid regulation of energy balance. Nat Med 2010, 16:1001-1008.

42. Whittle AJ, Carobbio S, Martins L, Slawik M, Hondares E, Vazquez MJ, Morgan D, Csikasz RI, Gallego R, Rodriguez-Cuenca S, et al: BMP8B increases brown adipose tissue thermogenesis through both central and peripheral actions. Cell 2012, 149:871-885.

43. Cypess AM, Lehman S, Williams G, Tal I, Rodman D, Goldfine AB, Kuo FC, Palmer EL, Tseng YH, Doria A, et al: Identification and importance of brown adipose tissue in adult humans. N Engl J Med 2009, 360:1509-1517.

44. Nedergaard J, Bengtsson T, Cannon B: Unexpected evidence for active brown adipose tissue in adult humans. Am J Physiol Endocrinol Metab 2007, 293:E444-E452

45. van Marken Lichtenbelt WD, Vanhommerig JW, Smulders NM, Drossaerts JM, Kemerink GJ, Bouvy ND, Schrauwen P, Teule GJ: Cold-activated brown adipose tissue in healthy men. N Engl J Med 2009, 360:1500-1508.

46. Virtanen KA, Lidell ME, Orava J, Heglind M, Westergren R, Niemi T, Taittonen M, Laine J, Savisto NJ, Enerback S, et al: Functional brown adipose tissue in healthy adults. N Engl J Med 2009, 360:1518-1525.

47. Schoder $H$, Larson SM, Yeung HW: PET/CT in oncology: integration into clinical management of lymphoma, melanoma, and gastrointestinal malignancies. J Nucl Med 2004, 45(Suppl 1):72S-81S.

48. Hany TF, Gharehpapagh E, Kamel EM, Buck A, Himms-Hagen J, Von Schulthess GK: Brown adipose tissue: a factor to consider in symmetrical tracer uptake in the neck and upper chest region. Eur J Nucl Med Mol Imaging 2002, 29:1393-1398.

49. Saito M, Okamatsu-Ogura Y, Matsushita M, Watanabe K, Yoneshiro T, NioKobayashi J, Iwanaga T, Miyagawa M, Kameya T, Nakada K, et al: High incidence of metabolically active brown adipose tissue in healthy adult humans: effects of cold exposure and adiposity. Diabetes 2009, 58:1526-1531.

50. Jacobsson H, Bruzelius M, Larsson SA: Reduction of FDG uptake in brown adipose tissue by propranolol. Eur J Nucl Med Mol Imaging 2005, 32:1130.

51. Soderlund V, Larsson SA, Jacobsson H: Reduction of FDG uptake in brown adipose tissue in clinical patients by a single dose of propranolol. Eur J Nucl Med Mol Imaging 2007, 34:1018-1022.

52. Zingaretti MC, Crosta F, Vitali A, Guerrieri M, Frontini A, Cannon B, Nedergaard J, Cinti S: The presence of UCP1 demonstrates that metabolically active adipose tissue in the neck of adult humans truly represents brown adipose tissue. FASEB J 2009, 23:3113-3120.
53. Tang W, Zeve D, Suh JM, Bosnakovski D, Kyba M, Hammer RE, Tallquist MD Graff JM: White fat progenitor cells reside in the adipose vasculature. Science 2008, 322:583-586.

54. Atit R, Sgaier SK, Mohamed OA, Taketo MM, Dufort D, Joyner AL, Niswander L, Conlon RA: Beta-catenin activation is necessary and sufficient to specify the dorsal dermal fate in the mouse. Dev Biol 2006, 296:164-176.

55. Timmons JA, Wennmalm K, Larsson O, Walden TB, Lassmann T, Petrovic N, Hamilton DL, Gimeno RE, Wahlestedt C, Baar K, et al: Myogenic gene expression signature establishes that brown and white adipocytes originate from distinct cell lineages. Proc Natl Acad Sci U S A 2007, 104:4401-4406.

56. Kajimura S, Seale P, Kubota K, Lunsford E, Frangioni JV, Gygi SP, Spiegelman BM: Initiation of myoblast to brown fat switch by a PRDM16-C/EBP-beta transcriptional complex. Nature 2009, 460:1154-1158.

57. Tseng YH, Kokkotou E, Schulz TJ, Huang TL, Winnay JN, Taniguchi CM, Tran $\Pi$, Suzuki R, Espinoza DO, Yamamoto Y, et al: New role of bone morphogenetic protein 7 in brown adipogenesis and energy expenditure. Nature 2008, 454:1000-1004

58. Seale P, Bjork B, Yang W, Kajimura S, Chin S, Kuang S, Scime A, Devarakonda $\mathrm{S}$, Conroe HM, Erdjument-Bromage $\mathrm{H}$, et al: PRDM16 controls a brown fat/skeletal muscle switch. Nature 2008, 454:961-967.

59. Wu J, Bostrom P, Sparks LM, Ye L, Choi JH, Giang AH, Khandekar M, Virtanen KA, Nuutila P, Schaart G, et al: Beige adipocytes are a distinct type of thermogenic fat cell in mouse and human. Cell 2012, 150:366-376.

60. Oberkofler H, Dallinger G, Liu YM, Hell E, Krempler F, Patsch W: Uncoupling protein gene: quantification of expression levels in adipose tissues of obese and non-obese humans. J Lipid Res 1997, 38:2125-2133.

61. Vegiopoulos A, Muller-Decker K, Strzoda D, Schmitt I, Chichelnitskiy E, Ostertag A, Berriel DM, Rozman J, de Hrabe AM, Nusing RM, et al: Cyclooxygenase- 2 controls energy homeostasis in mice by de novo recruitment of brown adipocytes. Science 2010, 328:1158-1161.

62. Bostrom P, Wu J, Jedrychowski MP, Korde A, Ye L, Lo JC, Rasbach KA, Bostrom EA, Choi JH, Long JZ, et al: A PGC1-alpha-dependent myokine that drives brown-fat-like development of white fat and thermogenesis. Nature 2012, 481:463-468.

63. Ohno H, Shinoda K, Spiegelman BM, Kajimura S: PPARgamma agonists induce a white-to-brown fat conversion through stabilization of PRDM16 protein. Cell Metab 2012, 15:395-404.

64. Aversa A, Caprio M, Antelmi A, Armani A, Brama M, Greco EA, Francomano D, Calanchini M, Spera G, Di LL, et al: Exposure to phosphodiesterase type 5 inhibitors stimulates aromatase expression in human adipocytes in vitro. J Sex Med 2011, 8:696-704.

65. Moro C, Klimcakova E, Lafontan M, Berlan M, Galitzky J: Phosphodiesterase$5 \mathrm{~A}$ and neutral endopeptidase activities in human adipocytes do not control atrial natriuretic peptide-mediated lipolysis. Br J Pharmacol 2007 152:1102-1110.

66. Zhang $X$, Ji J, Yan G, Wu J, Sun $X$, Shen J, Jiang H, Wang $H$ : Sildenafil promotes adipogenesis through a PKG pathway. Biochem Biophys Res Commun, 396:1054-1059.

67. De TL, Strapazzon G, Gianesello L, Caretta N, Pilon C, Bruttocao A, Foresta C: Effects of type 5-phosphodiesterase inhibition on energy metabolism and mitochondrial biogenesis in human adipose tissue ex vivo. $J$ Endocrinol Invest 2011, 34:738-741.

68. Armani A, Marzolla V, Rosano GM, Fabbri A, Caprio M: Phosphodiesterase type 5 (PDE5) in the adipocyte: a novel player in fat metabolism? Trends Endocrinol Metab 2011, 22:404-411.

69. Perwitz N, Wenzel J, Wagner I, Buning J, Drenckhan M, Zarse K, Ristow M Lilienthal W, Lehnert $H$, Klein J: Cannabinoid type 1 receptor blockade induces transdifferentiation towards a brown fat phenotype in white adipocytes. Diabetes Obes Metab 2010, 12:158-166.

70. Lee JY, Takahashi N, Yasubuchi M, Kim Yl, Hashizaki H, Kim MJ, Sakamoto T, Goto T, Kawada T: Triiodothyronine induces UCP-1 expression and mitochondrial biogenesis in human adipocytes. Am J Physiol Cell Physiol 2012, 302:C463-C472.

71. Stock MJ, Rothwell NJ: Role of brown adipose tissue thermogenesis in overfeeding: a review. J R Soc Med 1983, 76:71-73.

72. Ouellet V, Labbe SM, Blondin DP, Phoenix S, Guerin B, Haman F, Turcotte EE, Richard D, Carpentier AC: Brown adipose tissue oxidative metabolism contributes to energy expenditure during acute cold exposure in humans. J Clin Invest 2012, 122:545-552. 
73. Chen YI, Cypess AM, Sass CA, Brownell AL, Jokivarsi KT, Kahn CR, Kwong KK: Anatomical and Functional Assessment of Brown Adipose Tissue by Magnetic Resonance Imaging. Obesity (Silver Spring) 2012, 20:1519-1526.

74. Tseng YH, Cypess AM, Kahn CR: Cellular bioenergetics as a target for obesity therapy. Nat Rev Drug Discov 2010, 9:465-482.

75. Huttunen P, Hirvonen J, Kinnula V: The occurrence of brown adipose tissue in outdoor workers. Eur J Appl Physiol Occup Physiol 1981, 46:339-345.

76. Arch JR: The discovery of drugs for obesity, the metabolic effects of leptin and variable receptor pharmacology: perspectives from beta3adrenoceptor agonists. Naunyn Schmiedebergs Arch Pharmacol 2008, 378:225-240.

77. Clapham JC, Arch JR: Thermogenic and metabolic antiobesity drugs: rationale and opportunities. Diabetes Obes Metab 2007, 9:259-275.

78. Bryzgalova G, Effendic S, Khan A, Rehnmark S, Barbounis P, Boulet J, Dong G, Singh R, Shapses S, Malm J, et al: Anti-obesity, anti-diabetic, and lipid lowering effects of the thyroid receptor beta subtype selective agonist KB-141. J Steroid Biochem Mol Biol 2008, 111:262-267.

79. Villicev CM, Freitas FR, Aoki MS, Taffarel C, Scanlan TS, Moriscot AS, Ribeiro MO, Bianco AC, Gouveia CH: Thyroid hormone receptor beta-specific agonist GC-1 increases energy expenditure and prevents fat-mass accumulation in rats. J Endocrinol 2007, 193:21-29.

80. Petrovic N, Walden TB, Shabalina IG, Timmons JA, Cannon B, Nedergaard J: Chronic peroxisome proliferator-activated receptor gamma (PPARgamma) activation of epididymally derived white adipocyte cultures reveals a population of thermogenically competent, UCP1containing adipocytes molecularly distinct from classic brown adipocytes. J Biol Chem 2010, 285:7153-7164.

81. Vernochet C, Peres SB, Davis KE, McDonald ME, Qiang L, Wang H, Scherer PE, Farmer SR: C/EBPalpha and the corepressors CtBP1 and CtBP2 regulate repression of select visceral white adipose genes during induction of the brown phenotype in white adipocytes by peroxisome proliferator-activated receptor gamma agonists. Mol Cell Biol 2009, 29:4714-4728.

82. Smith SR, De JL, Volaufova J, Li Y, Xie H, Bray GA: Effect of pioglitazone on body composition and energy expenditure: a randomized controlled trial. Metabolism 2005, 54:24-32.

83. Scheen AJ, Van Gaal LG, Despres JP, Pi-Sunyer X, Golay A, Hanotin C: Rimonabant improves cardiometabolic risk profile in obese or overweight subjects: overview of RIO studies. Rev Med Suisse 2006, 2:1916-1923.

84. Samat A, Tomlinson B, Taheri S, Thomas GN: Rimonabant for the treatment of obesity. Recent Pat Cardiovasc Drug Discov 2008, 3:187-193.

85. European Medicines Agency: The European Medicines Agency recommends suspension of the marketing authorization of Acomplia, Doc. Ref.: EMEA CHMP/537777/2008. Press release Oct 23; 2008 [http://www.emea.europa.eu].

doi:10.1186/1758-5996-4-43

Cite this article as: Haas et al:: Targeting adipose tissue. Diabetology \& Metabolic Syndrome 2012 4:43.

\section{Submit your next manuscript to BioMed Central and take full advantage of:}

- Convenient online submission

- Thorough peer review

- No space constraints or color figure charges

- Immediate publication on acceptance

- Inclusion in PubMed, CAS, Scopus and Google Scholar

- Research which is freely available for redistribution

Submit your manuscript at www.biomedcentral.com/submit
( Biomed Central 